\title{
Japan and Zhongdong Railway Incident
}

\author{
Hongjun Zhang \\ Institute for Local History of the Party, Liaoning Academy of Social Sciences \\ No. 86, Taishan Road, Huanggu District, Shenyang 110031, Liaoning, China \\ Tel: 86-24-8612-0483Ｅ-mail: hongjun1957@163.com
}

\begin{abstract}
It has been for quite some time the conspiracy that Japan invaded China and seized the Northeast. In the process of its implementation of the conspiracy, there had a vehement interest conflict between Japan and Soviet Russia. After the Japan-Russia War, Northeast China became a sphere of influence between Russia and Japan, but they fought against each other continually for Zhongdong Railway issue. After the September 18 Incident, situation of Zhongdong Railway was in depression, together with threat of Puppet Manchu, so in 1933, Soviet Union government transferred all its authority in Zhongdong Railway to "Manchuria Government" in a paid form. Japan eventually achieved its purpose.
\end{abstract}

Keywords: Japan, Zhongdong Railway, Soviet Union

After Japan-Russia War, according to "Treaty of Portsmouth" in 1905, Tsarist Russia ceded to Japan the section of Zhongdong Railway from Changchun to Dalian, and recalled it South Manchurian Railway. In addition, Tsarist Russia still took control over the section which was centered with Harbin, extended to Suifenhe (east line) in the east, to Manzhuli (west line) in the west and to Changchun (south line) in the south. Thence, the Northeast China was marked by the railway, with Changchun as the boundary, which respectively became the sphere of influences between Japan and Russia. The history told us that, once a country had a wild ambition towards a place and intended to embrace her under its control, it would try all its best to occupy her lifeline --- railway route --- as its power. Japan knew for sure that, it had to primarily control Zhongdong Railway in order to expand its power to North Manchuria. What's more, the economic transportation of Zhongdong Railway had a close connection with the operation of the railway in South Manchuria.

\section{Role of Manchurian Railway}

The history of Japanese imperialists' invasion in the Northeast China was not only a railway invasion history centered with Manchurian Railway, but also a fight history in which Zhongdong Railway and South Manchurian Railway absorbed their economic profits. In 1906 after Japan-Russia War, South Manchuria Railways Co. (SMR for short) was established, so a thorough railway invasion policy began which was centered with Manchurian Railway. On the surface, Manchurian Railway was an organization to operate south railway, but as a matter of fact, it was a great base camp for Japanese economic pillage and conspiracy on the Northeast China, and regarded "operation and development of Manchuria" as its own duty. As the representative of Japanese new national policy, the Chairman of Manchurian Railway had to be the primary character to realize the new World Policy of Japan. Furthermore, like the general manager of East India Company, he should be the go-getter who fought in the van for realization of the expansion policy of Japan. Either the first Chairman Goto Shinpei or the last Chairman Shanqiyuan had played a significant role in "operation and development of Manchuria". In 1927 when Japanese foreign affairs and army held a conference, they constituted the following policies, which was so-called "Great Manchurian Railwayism". (1) SMR was established upon close connection between foreign affairs and army and implemented their policies. Manchurian Railway Centrism made it easier to thoroughly implement their policies, which was aimed at expanding their rights and becoming "Great Manchurian Railwayism". (2) As for policies of the three provinces in Northeast China, it was the Army and Foreign Affairs to keep contact with so as to achieve stability of political situations. Japan also anticipated that political fights within China wouldn't spread to the three provinces at all, so that Japanese in Manchuria and Mongolia would lead a stable life. (3) A tariff agreement about Zhongdong Railway should be put forward immediately so as to anticipate perfect relations with Soviet Union. (4) Japan should set commercial land rent rights so as to negotiate actively with Chinese. (5) Japan would attempt to persuade China to set up a central back in the three provinces as a presenting bank. Assets required could be contributed by Manchurian Railway by negotiation with China. 
After Japan-Russia War, Japan gained a monopolized position in South Manchuria, and possessed Guandong Hall and SMR as its two great camps to invade China. The economic invasion was the primary and political invasion was secondary, and cultural invasion was tried. Those who intended to implement "Great Manchurian Railwayism" planned to diminish rights of Guandong Hall, and enlarge rights of SMR. Although "Great Manchurian Railwayism" hadn't been involved in the issue of Zhongdong Railway, still it was without doubt that Zhongdong Railway was its target.

Since the end of WWI, taking back of Zhongdong Railway had been of great urgency. In the second half year of 1927 , the Soviet Union Government was provoked by Japanese "Manchuria and Mongolia", and awed by increasingly rising voice of Chinese to take back sovereignty of Zhongdong Railway, and it was difficult for the Soviet Union Government to deal with this situation. In order to maintain its interests in Zhongdong Railway and with planning of several parties, the Government took all its cost to transfer Zhongdong Railway to its enemy for centuries --- Japan. On September 8, 1927, the SMR Chairman Yamatoto Taro went to Harbin for "inspection" because he heard that China planned to take back Zhongdong Railway. On October 12, 1927, the Russian Deputy Director General of Zhongdong Railway went to Dalian and discussed specific conditions with SMR. The Soviet Union Government was willing to transfer the ownership of Zhongdong Railway to Japan, which was at the cost of borrowing 40 million Japanese yen. Zhongdong Railway manager and SMR Chairman Yamatoto Taro signed "Zhongdong Railway Protocol", whose content was as follow. (1) Japanese Government ordered SMR to deal with Zhongdong Railway. (2) Japan and Russia were against China to take back Zhongdong Railway. (3) SMR allowed Russia to send soldiers to protect the north section of Zhongdong Railway, but the number of soldiers was limited to 5600. (4) Japanese goods transportation should be treated with priority in Zhongdong Railway and Wusuli Railway. (5) South Songhua River was firstly transferred to Japanese SMR in Zhongdong Railway, which was decided to be implemented within one year. (6) Japan laid railway in Inner Mongol and North Manchuria, and Russia should assist it, for which the Soviet Union Government should send engineers and plan all issues together with Japanese personnel. (7) Japan and Russia took advantage of Mongolia and the two countries negotiated with the principle of equalization. (8) Russia allowed Japan to exploit forests, coal, iron, and oilfields etc in Siberia and Heilongjiang, but with the precondition that Japan allowed Russia to transport any file by way of Japan to Europe and America, etc.

Soviet Union transferred Zhongdong Railway just like its private property and signed protocols privately with others, which violated spirit of Chinese and Russian agreement, and which was an action that extremely despised China and badly defied Chinese sovereignty. Japan's ambition to invade North Manchuria and merger Zhongdong Railway was also obvious. Although they signed the protocol secretly, the news still spread like wildfire. It was America who got the news at first, and it paid special attention to that. After coming into knowledge, the Chinese Government was extremely surprised, and enquired Japan for that issue. Japan justified that, It was Russia's right to transfer Zhongdong Railway, and those rights which were supposed to belong to China still existed, and wouldn't be affected by transfer between Japan and Russia. Actually, it had been for quite some time since Japan tried to enlarge its power in North Manchuria and coveted Zhongdong Railway. When the October Revolution of Russia broke out, Japan seized the opportunity to attack Siberia, and it had intended to merger Zhongdong Railway. However, the railway was temporarily controlled by such seven countries as China, Soviet Union, Japan, America, England, France and Italy, Japan didn't accomplish its purpose. During the Washington Conference, although those countries present negotiated that China should be responsible for all issues related with the railway, yet Japan made an excuse for joint venture investment and tried its best to interfere. It was not until 1929 that governments of the two countries admitted that the future of Zhongdong Railway could only rest with China and Russia, and that no other country should involve in that. Although Japan was disappointed, its ambition to invade the North Manchuria and take control over Zhongdong Railway was not be diminished anyhow since there was a close connection between Zhongdong Railway and Manchurian Railway. On the contrary, its ambition was on the increase. In compliance with decree order of Japanese Government, SMR was quite active and exhibited great ambition to be insatiable and swallow the Northeast China.

\section{Countermeasures of Japan}

Before the Zhongdong Railway Incident, Japan had held a general mobilization practice in Kyoto, Osaka and Hyogo. This practice was supervised by USAMI Resource director and former Osaka was the supervision department. And it was supposed that after breaking off from diplomatic relations, the practice of general mobilization would begin. That very day, not only airplanes were dispatched, but factories around the whole country tried their power in the three aspects, namely, "manufacture", "confiscation" and "ammunition transportation". Such an unprecedented practice in the peaceful period was enough to arouse any doubt. After the Zhongdong Railway Incident, Japan went from bad to worse in that they made long-term siege practice in Changchun and even regarded Shenyang as their target.

After the Zhongdong Railway Incident, Japanese were quite active in South Manchuria and in any international activities, and adopted a positive policy.

\subsection{Sending more troops}

On August 2, Nanjing received a telegraph from Shenyang that, in order to consolidate its power in South Manchuria, 
Japan had sent approximately 5 thousand soldiers in South Manchurian Railway, and it was said that it would continue to send more troops there. Japanese Consulate in Changchun informed all all sections of South Manchurian Railway and Guangdong Army headquarter built a large number of army barracks in Changchun, for which the construction expense should cost two million Yuan or so, and about 1,600 workers were required. The construction should be started in middle August. On August 29, the Communications Corporation made a telegraph to Tokyo, "Two squadrons of 1,800 artillerymen were sent respectively to Tieling and Anshan Station. So far, Japanese troops have already reached 13,000 soldiers."

\subsection{Practice battle}

At that time, Japanese garrisons in South Manchuria would launch a military practice in spring and autumn, but never in hot seasons when crops were frondent. That time was a period when relations between China and Russia were critical and will the people was unstable. Guandong Army headquarter suddenly ordered Japanese troops in Manchuria to launch a long-term siege practice from August 1 to September 10. The $38^{\text {th }}$ regiment of Japanese army in Changchun marched out of the concession last night. They didn't notice our local authority, and after the event, they destroyed lots of crops. Not a single village they passed didn't suffer from a false alarm. Japanese commanding officer Matsui came from Dalian to Changchun in July $28^{\text {th }}$ for inspection of the army. The $33^{\text {th }}$ regiment of Japanese army in Shenyang surrounded Shenyang for military practice, and took dependencies of Japanese station as the major camp, which extended to Santaizi, Bajiazi, Wujiatun and Wangjiatun in the north, to Dengjiahuang, Xitutaizi and Shalingbao in the west, to Hunhe coast, Wangjiahe and Longwangmiao in the south and to Dongling etc in the east. Then they classified the following areas as sector of fire for soldiers: Lishanzi, Zhangiatun, Yanjiapao and Deshengying. The whole army was divided into two squadrons of attack and defense for interactive practice. Japanese directly regarded Shenyang as their target. On August 18, it was reported that, "four thousand Japanese soldiers conducted military practices surrounding Shenyang which was aimed at holding a protest demonstration. Chinese people were quite angry with that and asked negotiation office to protest against Japan. However, without waiting for proposal of protest file, Japanese army again conducted artillery action outside Shenyuan, with endless firearm sound. This unscrupulous rampage of Japanese was no less than the first sign of weapon invasion."

\subsection{Immigration}

Immigration of Japanese towards the three provinces in Northeast China was one of their "three major national policies". In order to enlarge their power, Japanese seized each chance just like split quicksilver covering the whole ground. According to news about Japanese from Shenyang, South Manchurian Railway's operation of agricultural corporation stipulated that, from this autumn to next spring, immigration to South Manchuria will be carried out and those immigrants will undertake planting. The general methods are as follows: (1) Land that had been bought was to be assigned to farmers, and each household could take thirteen Shang of long-cultivated land (each Shang approximates to six $\mathrm{Mu}$ or ten $\mathrm{Mu}$ ). The price of each Shang of land was worth a hundred of Japanese yen or so. (2) Japanese government subsidized farmers a total of eight hundred Japanese yen for their planting, boats, vehicles and houses. (3) Those earliest immigrants resided in Hedongtun, Xichengzi, Shaojiatun and Shajiatun etc within Yanziwo in Dalian, and twenty or thirty households could constitute a village.

\subsection{Formulation of invasion plan}

According to World News Agency in Jilin, "Recently, the head of Yanji negotiation office Zhang Shuhan listed four new plans of Japanese invasion in the three provinces of Northeast China. He reported this to Jilin Government and requested local authority to try to deal with the situation. His description was as follows. (1) Japanese excessively set up police force in Yanji, and it had been a long time since they had invaded Chinese administrative police power. Recently, Japanese people set up police wherever Japanese people yard up. They made an excuse that Chinese people resisted Japanese and that Japanese should be protected by Japanese police, so they were protected by Japanese police in places which Chinese local police couldn't control. (2) Japanese people pretended skillfully as Chinese businessmen or Korean farmers and visited all places for measuring the geographical condition and prying into the national situation. Chinese local authority arrested them, while Japanese took advantage of their consular jurisdiction for requirement of extradition and for immediate release. (3) In Yanji, Japanese attempted to support its economic power, and had already had the foundation of consolidation. Chinese people trusted Japanese currency, but didn't trust their own provincial currency. (4) Japanese people extensively set up educational institutions. They recruited children of Korean farmers to prevent them from being assimilated by China, and to invade Chinese culture.

\subsection{Preventing Chinese military vehicles from passing through Changchun}

After the incident, Soviet Union army sent mass troops to Chinese frontier, and for self-defense, China had to make necessary military preparations. "Japanese Manchurian army headquarter ordered South Manchurian Railway not to transport weapons urgently needed by Chinese army, and forbade Chinese soldiers passing through area of South Manchurian Railway. Those who allowed to be disarmed and who were allowed to pass by local Japanese headquarter 
could be let go. On August 21, it was reported that, "Chinese trains which carried Chinese soldiers are obstructed by Japanese army in South Manchurian Railway, and cannot pass through Changchun Station. Chinese local authority is building a road to connect Jichang and Zhongdong Railway." According to Wenhui News, there were several Japanese officers in Soviet Union army. It was said that, there was an agreement between Japan and Russia that Japan assisted Soviet Union, while the latter would transfer its fishery interests in Sakhalin Island to Japan. It was also reported that Japan was opposed to America's proposal to interfere in relations between China and Soviet Union. Wasn't it more obvious that Japanese were full of ambitions and aggressive?

\subsection{Unilateral mediation}

After Zhongdong Railway Incident, information of international conciliation was widely reported. According to $<<$ Zhongdong Railway Protocol $>>$, this incident should be automatically resolved by China and Russia. However, some countries intended to take the opportunity to intervene so as to benefit from it. The situation of "unilateral Japanese conciliation" and "conciliation of four countries" appeared in succession. Especially, the intention of "unilateral Japanese conciliation" was inclement. After the incident, one hand, Japan spoke openly to reconcile, and advocated "Asian Major". They said that European and American countries needn't take pains to care about issues in Asia, so there was no need for them to reconcile. It seemed that only Japan could monopolize issues in Asia. On the other hand, Japan continued to send troops to South Manchurian Railway. Meanwhile, they made use of telecommunications offices to bring about rumors and create a martial atmosphere, so that Japan could again take the opportunity to send more troops and to benefit a lot. At that time, Japanese Government expressed to Russian ambassadors in Japan that issues between China and Russia couldn't be resolved without Japanese conciliation, and that only Japan was allowed to reconcile, not others countries. It was obvious that they had ulterior motives.

However, other great countries were reluctant that Japan controlled the situation itself, and then action of "conciliation of four countries" was taken, which was firstly initiated by USA. According to KUMINSHA's telegraph in Washington On $19^{\text {th }}$, "American Secretary of State Christensen is trying to persuade ambassadors of England, France and Japan so as to maintain justice together with those three countries, and to resolve disputes of Chinese and Russian Zhongdong Railway with a fair procedure." England and France totally agreed with proposal of USA, but Japanese Government didn't express definitely its opposite attitude. In order to cater for purpose of Japanese Government, Japanese public opinions affirmatively stated that they didn't approve conciliation advocated by USA. They said that Japan was closely connected with the current situation, and any country should take careful consideration before any practical decision was made. It was obvious that the intention of Japan was to achieve unilateral conciliation, the precondition of which was to oppose USA and France, which, as a matter of fact, was so.

\subsection{Road construction}

Japan started construction in Jihui Railway which they had long been focusing on. "Involved in issues with Russia in South Manchurian Railway, we therefore send more ships to transport materials into Huining by way of Tiantu Railway. We start construction from Jihui Line and lay tracks in Fuzhen." At the same time, Japanese Nippon Yusen Kaisha determined to add ships to sail through Yingkou, Dalian and Vladivostock. During negotiation on Zhongdong Railway, North Manchurian materials had to pass through Ang'angxi and taonan, and then transported to South Manchuria.

Action of Japan in Northeast China was far beyond what was previously stated. But that was enough for us to know clearly situations in South Manchuria and countermeasures of Japan. After the incident, Japan took active actions and the situation was indeed serious.

\section{Japan benefited from Zhongdong Railway Incident.}

The period after Zhongdong Railway Incident was, of course, a hard-won opportunity for Japan. This disordered situation was exactly what it had been dreaming of, because in such a situation, it could make an excuse of protecting China to fish in troubled waters. In addition, it could obtain economic interests in terms of railway transportation. Japan could benefit a lot from mutual conflicts of China and Soviet Union. Before Zhongdong Railway Incident, it had the tendency that Zhongdong Railway would overwhelm South Manchurian Railway, but after the incident, the situation was exactly the opposite. According to data, situations of the two railways before and after the incident can be analyzed and compared.

\subsection{Situations of the two railways before Zhongdong Railway incident}

According to World News Agency, "It was Japan that benefited the most from conflict between China and Soviet Union, so it ignored provocation from all parties to bring about fracture. As for its profits gained, it was only Manchurian Railway in terms of economic, and it had gained quite a lot. It was investigated that goods from Manchuria and Mongolia were exported by way of two railways. Ratio of export amount of these two railways had gradually approximated to equalization by the year 1922 to 1926 . See the list as follows: 


\begin{tabular}{l|c|l|c|c|c}
\hline & \multicolumn{1}{|l|}{1922} & 1923 & 1924 & 1925 & 1926 \\
\hline $\begin{array}{l}\text { Proportion of } \\
\text { exportation } \\
\text { Weikou \% }\end{array}$ & 47 & 30 & 36 & 43 & 49 \\
\hline $\begin{array}{l}\text { Proportion of } \\
\text { exportation from } \\
\text { Dalian \% }\end{array}$ & 53 & 61 & 64 & 57 & 51 \\
\hline
\end{tabular}

If this situation doesn't change, then it might approach towards equalization several years later, or the ratio might be totally the opposite, or might be unknown.

\subsection{Situations of the two railways after Zhongdong Railway incident}

Since the Zhongdong Railway Incident, Wusuli Railway was blocked up, so goods were accumulated to 1,800 vehicles, altogether 1,810,000 Pute (Russian measurement unit). Meanwhile, situation of South Manchurian Railway was flourishing all of a sudden and freight income increased to over 10 million Japanese yen. In face of such an obvious comparison, Japanese people rejoiced in the calamity of others. Besides, entrusted by Japanese Ministry of Finance to investigate influences of Chinese and Russian issues on Japanese trade financing and other economic aspects, Korean Bank reported its investigation results to it. The general points were as follows. Uneasiness of North Manchuria was extended more than 60 days, which had perfect effect on Japanese economy. For instance, import amount of North Manchuria was 130 million Yuan or so each year, of which 85\% passed through South Manchurian Railway and 15\% passed through Wusuli Railway and Beikaer Railway. In addition, justified import income was 15 million Yuan and smuggler income was 4 million Yuan by way of Heilongjiang and Songhuajiang. Excluding justified income, smuggler income was 4 million Yuan among North Manchurian import amount. And import amount of North Manchuria was approximately 180 million Yuan each year. Because the primary import item cotton couldn't go through Vladivostock, it had to pass South Manchurian Railway. Especially, products of Mongolia couldn't get through Weibu, and had to pass South Manchurian Railway, so the Railway levied an amount of at least over 8 million Yuan each year. What was more favorable to Japan, corniness, tea, lean meat, potherb and grease etc, purchased by Russia from China had to be changed into Japanese goods and had to be purchased from Japanese people. Besides, kerosene, wood, horns, and tabacco etc, had to be changed into Japanese goods and had to be purchased from Japanese people.

Meanwhile, Japanese found an excuse to cause disturbance in Northeast China with South Manchurian Railway (including all branch lines) and its dependencies as the base. Japanese Government also enlarged railways under its monopoly and control and "dependencies of Manchurian Railway" by means of constructing new railways and branch lines in Northeast. Furthermore, it increased its investment there and gained high amount of profits. According to all sorts of historical records, railways controlled by Japan in Northeast China was 1,3445 kilometers in 1921 (including 235.4 kilometers which were controlled by means of loaning), and had already increased to 2,3608 kilometers before September $18^{\text {th }}$ Incident in 1931. Besides, according to relevant annual bulletins of "Manchurian Railway", "dependencies of Manchurian Railway" by Japan occupied an area of about 438,100 Mu in 1920, and increased to $623,520 \mathrm{Mu}$ in 1930. Total assets of Manchurian Railway were 503,533,000 Yuan in 1919, and increased to $1,034,594,000$ Yuan in 1929. Its transportation operation profit was 48,560,000 Japanese yen in 1920 and increased to $74,890,000$ Japanese yen in 1920. It can be discovered that, Japan gained huge economic profits from Zhongdong Railway Incident. What's more, Japan took strict control over situation in Northeast China through this increasingly enlarged "state within a state", and caused serious threat to security in Northeast China.

Earlier in 1932, Japanese army occupied all the three provinces of Northeast China. Soviet Union Government expressed its condemn and sympathy respectively to Japanese invasion and Chinese anti-Japan war. Local authority of Soviet Union declared again and again that, they were absolutely opposed to the policy of military occupation, and they respected international protocols signed with China. In 1932, Soviet Union recovered diplomatic relation between China and Soviet Union that was interrupted by Zhongdong Railway Incident. However, it was a pity that the previous standpoints of Soviet Union didn't stand for long. In March 1932, "Manchuria" under control of Japan was established. Before long, under pressure of Japan and Manchuria, Soviet Union Government declared that they confirmed sovereignty of Manchurian Government on Zhongdong Railway, and it would operate Zhongdong Railway together with Manchurian Government. Thence, Zhongdong Railway was changed from co-control by China and Soviet Union to co-control by Soviet Union and "Manchuria", from which it was obvious that Soviet Union admitted existence of "Manchuria". After co-control on Zhongdong Railway by Soviet Union and Manchuria, because Japan constantly dispatched troops and weapons there, and Japan and Manchuria often made disturbance, revenue from Zhongdong Railway fell sharply. In face of such a stagnant prospect and together with threat of Japan and Manchuria, Soviet Union Government formally proposed Japan to sell Zhongdong Railway in May 1933. The behavior of giving away Chinese sovereignty immediately aroused opposition among Chinese people. However, Soviet Union eventually transferred all rights of Zhongdong Railway to "Manchurian Government" with a price of 140 million Japanese yen, and Japan finally 
achieved its purpose.

After Zhongdong Railway Incident, Zhongdong Railway did have the danger to be transferred to Japan by Soviet Union, and together with other reasons, northeast authorities led by Zhang Xueliang sent troops to search Russian consulate in Harbin and took over Zhongdong Railway. The incident caused far-reaching influences to China, as a result of which China indirectly lost its power in Northeast China to contend against Japan, and which laid the path for Japan to launch its invasion in Northeast China. Rapid failure of the Northeast Army exposed actual situation of Northeast Army that they were an ass in a lion's skin, and also directly encouraged Japanese Kwantung Army's determination to take action.

\section{References}

(1929). Desire of Japan to Send Soldiers to Manchuria. Minguo Ribao, August 1.

(1929). Japanese Obstruction of Chinese Relations with Russia. Minguo Ribao, July 24.

(1929). Negotiation of China and Russia, and Benefit of Japan. Minguo Ribao, August 3.

(1977). Selected Works of Historical Records on Modern China's Foreign Relations: 1840-1949 (First Fascicule of the Second Volume). Shanghai People's Publishing House, 23.

(1986). Economic History of Northeast. Sichuan People's Publishing House, 327-328.

$\mathrm{Fu}$, Jiaojin. (1929). Study on Issues of Zhongdong Railway (One Volume in all). World Books, 29, 28, 31.

Jiang, Xingde. Background and Political Reflections of Zhongdng Railway. Eastward Magazine, Vol. 26, No. 15, 26.

Liu, Huiwu \& Liu, Xuezhao. (1984). A Brief History of the Japanese invasion of China. East China Normal University Press, 43.

Song, Hua. Situation of South Manchuria after the Incident of Zhongdong Railway. Eastward Magazine, Vol. 26, No. $15,4-5$.

Yu, Gan. Situations of All Parties after Zhongdong Railway Incident. Eastward Magazine, Vol. 26, No. 14, 1, 3. 